\title{
Isolation of Lactobacillus Sps from Yoghurt and its Application in Probiotic Chocolate
}

\author{
Kavitha .P' $\mathbf{P}^{1}$ Banumathi . $\mathbf{M}^{2}$, Sindhuja . $\mathbf{D}^{3}$ \\ Department of Microbiology, Srimad Andavan Arts and Science College, Trichy, India
}

\begin{abstract}
The isolated and identified bacteria from yoghurt sample are of spp. Lactobacillus. The bacteria of this spp. are lactic acid producers. These spp. resembles to Lactobacillus acidophilus. A probiotic is a microorganism known to be friendly and beneficial to its host when consumed. In today's time, probiotics are a very popular subject of research among scientists and pharmaceutical companies .Due to the over consumption of antibiotics, the normal micro flora of body does not survive.The spores obtained from pharmaceuticals are not good in taste, so generally children avoid eating them, hence we have made the probiotic chocolate. It is better to eat chocolate than medicine. The chocolate containing lyophilized Lactobacillus spp. may help directly for enhancing resistance against intestinal pathogens and in the prevention of diseases
\end{abstract}

Keywords: Probiotics, Lactobacillusbulgaricus, lyophillization, Probiotic chocolate

\section{Introduction}

Although many genera of bacteria produce lactic acid as a primary or secondary end-product of fermentation, the term Lactic Acid Bacteria is conventionally reserved for genera in the order Lactobacillales, which includes Lactobacillus, Leuconostoc, Pediococcus, Lactococcusand Streptococcus, in addition to Cornybacterium, Enterococcus. Yoghurt is a very good source for Lactobacillus species. Lyophillization technique is used for freeze drying of bacteria i.e. in the powdery form so we can easily add them into chocolate mixture. The viability of Lactobacillus species is not harmed in lyophillization technique upto some extent.

Probiotic microorganisms are often incorporated in food in the form of yoghurt and yoghurt type fermented food. Recently, there are probiotic ice cream, cheese, infant formulas, breakfast cereals, sausages, chocolate and puddings. Nondairy food also has been manufactured with the addition of the same types of microorganisms. In fact, there are also medical probiotics in the form of capsules and tablets.

\section{Materials Methods}

Yoghurt is the best source for lactobacillus spp. Among the other dairy products such as milk, buttermilk etc.Yoghurt is taken in sterilized flask. Under the aseptic conditions yoghurt was serially diluted from $10^{-1}$ to $10^{-14}$ from this 14 dilutions $10^{-5}, 10^{-7}, 10^{-9}$ are selected. For this 3 tubes spread plate technique further with streak plate technique is done on MRS medium. They are incubated in incubator $37^{\circ} \mathrm{C}$ which is optimum temperature for Lactobacillus broth. Incubation at $37^{\circ} \mathrm{C}$ for $24 \mathrm{hrs}$. Broth after 24-48 hrs shown Lactobacillus species growth and these species for 24 hours. After the period of incubation 3 isolated colonies were grown . Colony characterization is done for this 3 colonies found to be Lactobacillus species. 1 colony shows 100\% resemblance with Lactobacillus acidophilus. Further catalase test was done.

The isolated colony formed on the MRS agar plates was identified using gram stain, biochemical tests. The identification was performed according to Bergey's manual of determinative of bacteriology. The culture was kept in MRS agar slant and stored at $4^{0} \mathrm{c}$ for long term storage.

\section{Gram Staining Test}

The isolated bacterium were examined using gram staining kit and was observed under phase contrast microscope with a magnification of $10 x, 45 x$ and $100 x$.

\section{Motility Test}

Hanging-drop wet method was performed. The slide was observed under a light microscope with $45 \mathrm{x}$ magnification to check the motility of the bacteria.

\section{Catalase Test}

To perform this test, a single isolated colony was streaked on a glass slide and one drop of $3 \%$ hydrogen peroxide was added on to it. The effervescence of oxygen indicated the positive response of the bacteria to catalase test.

\section{Lyophilization}

One colony is taken from the yoghurt streak plated and inolculated in $1000 \mathrm{ml}$ of nutrient bacteria were freeze dried ( powdery form) using lyophilization technique.

\section{Preparation f Chocolate}

$200 \mathrm{gm}$ of milk powder and 2 Chocolate cubes (40gm) heated upto it melts. Then addition of some volume of milk (for solidification) is done. When it reaches the normal temperature, addition of freeze dried bacteria is done. Mixed it well and stored in freeze at low temperature. When it was solidified then cut into pieces. Wrapped the chocolates in Aluminium foil.

\section{Results and Conclusion}

\section{Identification of Lactobacillus SPP}

The isolated bacteria were observed by phase contrast microscope. It is clear that the bacteria was gram positive, rod shaped coccobacilli, occurring singly or in chains. The gram staining results indicated that the isolated bacteria could be identified as Lactobacillus acidophillus .Hangingdrop wet method showed that the isolated bacteria were 


\section{International Journal of Science and Research (IJSR) \\ ISSN (Online): 2319-7064 \\ Index Copernicus Value (2013): 6.14 | Impact Factor (2014): 5.611}

nonmotile The nonmotile behavior is a characteristic of L.acidophilus. Therefore the yoghurt sample 'bacterium resembles characters similar to Lactobacillus acidophilus. The catalase test is one of the most useful diagnostic tests for the recognition of bacteria due to their simplicity. In performing catalase test, no bubble was observed indicating that the isolated bacterium is catalase negative and could not mediate the decomposition of $\mathrm{H} 2 \mathrm{O} 2$ to produce $\mathrm{O} 2$. It is well known that Lactobacillus is catalase negative . Thus, the results obtained coincided with L. acidophilus strain characteristics.

\section{Lyophilization and Preparation of Probiotic Chocolate}

By using lyophilization technique the Lactobacillus species were freeze dried. The freeze dried Lactobacillus species were in powedery form. This powder was added at the last step of preparation of chocolate. The probiotic chocolate is prepared. The chocolate is easily assimilated and it is better to eat a chocolate than medicinal tablets.

\section{Cell Count}

$=\underline{\text { no. of cells in culture } \times 106}$ dilution factor

= for $1 \mathrm{ml}-146 \times 106$

$=$ for $1000 \mathrm{ml}-146 \times 109$

\begin{tabular}{|c|c|c|c|c|}
\hline $\begin{array}{c}\text { Lactobacillus } \\
\text { sp }\end{array}$ & L.acidophilus & L.lactis & L.casei & $\begin{array}{c}\text { L. } \\
\text { bulgaricus }\end{array}$ \\
\hline Shape & Rod & Cocci & Cocci & Rod \\
\hline Colour & White & $\begin{array}{c}\text { Yellowish } \\
\text { white }\end{array}$ & $\begin{array}{c}\text { Yellowish } \\
\text { white }\end{array}$ & White \\
\hline Colour & Mucoid & Moist & Moist & Mucoid \\
\hline $\begin{array}{c}\text { Gram } \\
\text { character }\end{array}$ & Gram +ve & Gram +ve & Gram +ve & Gram +ve \\
\hline Motility & Non motile & Non motile & Non motile & $\begin{array}{c}\text { Non } \\
\text { motile }\end{array}$ \\
\hline Endospore & Absent & Absent & Absent & Absent \\
\hline Capsule & Absent & Absent & Absent & Absent \\
\hline
\end{tabular}

\section{References}

[1] Barry Callebaut, First probiotic chocolate on industrial scale in partnership with Lal'food, Nov 28, 2007.

[2] S.Possemiers, M Marzorati, W Vrstraete, T Van De; Wiele International journal of food microbiology2010Volume:141,Issue:1-
2,Publisher:Elsevier
B.V.,Pages;
97103.Pubmed:20452073.

[3] M RatnaSudha, PrashantChauhan, Kalpana Dixit, SekharBabu, Kaiser Jamil, Genetic Engineering and Biotechnology Journal, Volume 2010.

[4] Lactospore, A lactic acid bacillus preparation, Sabinsa Corporation,

[5] Bergey's Manual of Systematic Bacteriology, first edition, vol. 2, The Williams \& Wilkins Co., Baltimore, 1986 .

[6] Todar's online textbook of bacteriology, Keenethtodar, $\mathrm{PhD}$.

[7] Hassan Par and K.K Peh, International Journal of Pharmacy and Pharmaceutical Sciences, Vol 6, Issue 1, 2014.
[8] G R. Nireesha, L. Divya, C. Sowmya, N.Venkateshan, M.NiranjanBabu and V.Lavakumar, International Journal Of Novel Trends In Pharmaceutical Sciences, Volume 3,Number 4, Oct, 2013. 